[3] Natalello G, De Luca G, Gigante L, et al. Nailfold capillaroscopy findings in patients with coronavirus disease 2019: Broadening the spectrum of COVID19 microvascular involvement. Microvasc Res. 2021;133:104071.

Disclosure of Interests: None declared

DOI: 10.1136/annrheumdis-2021-eular.4210

\section{AB0710 ANISOCYTOSIS INDEX AS AN EARLY PREDICATOR OF HOSPITAL MORTALITY IN PATIENTS WITH COVID- 19 PNEUMONIA FROM A LEVEL III HOSPITAL. LIMA PERU}

\section{J. Ravelo'. 'San Juan Bautista Clinic, Lima, San Juan de Lurigancho, Peru}

Background: RDW has been analyzed in recent decades as a poor prognostic factor, associated with an increased risk of mortality from all causes: heart disease, lung disease, sepsis, influenza, cancer, complications associated with heart failure, coronary disease, viral hepatitis, COPD, development of DM2, stroke and anemia, which makes it a nonspecific marker of disease with the potential to provide a stratified quantification of risk in a new disease.

Objectives: To determine if laboratory tests predict mortality in patients with COVID-19 pneumonia upon admission to hospital. Secondary outcome: evaluate if any laboratory parameter predicts longer hospitalization in patients with COVID-19 pneumonia.

Methods: Case control retrospective study of COVID-19 pneumonia patients, admitted to the Peruvian Air Force Hospital from April 6th to June 27th, 2020. Patients were divided in two groups: recovered and deceased and their laboratory parameters entered the statistical analysis. Cox regression was performed $(95 \% \mathrm{Cl}, \mathrm{p}$ value $<0.05$, as statistically significant). Bivariate analysis to compare the RDW means of recovered vs. deceased and multivariate analysis with binary logistic regression to evaluate the predictive value of RDW in relation to hospital mortality in our cohort. The statistical package Stata version 14.2 was used.

Results: 186 patients were included. The mean age of the recovered patients was $53.6 \pm 16.4$ years vs $75.9 \pm 13.9$ years in the deceased group $(p<0.0001)$. The mean value of RDW was $13.14 \%$ in recovered vs. $13.96 \%$ of deaths ( $p^{<}$ 0.0005), associated with an Odds Ratio (OR) of 1.66 (Cl: 1.58-1.74) adjusted for the model.

Conclusion: The finding of a RDW $\geq 13 \%$ in patients with COVID-19 pneumonia was associated with higher mortality.

REFERENCES:

[1] Imam Z, Odish F, Gill I, O'Connor D, Armstrong J, Vanood A, et al. Older age and comorbidity are independent mortality predictors in a large cohort of 1305 COVID-19 patients in Michigan, United States. J Intern Med. 2020 Jun 22. DOI: $10.1111 /$ joim. 13119

[2] Foy $\mathrm{BH}, \ldots \ldots$...

Table 1. Characteristics and comorbidities in patients with COVID-19 Pneumonia

\begin{tabular}{|c|c|c|c|c|c|}
\hline & & $\begin{array}{c}\text { Total } \\
\text { (N:188) }\end{array}$ & $\begin{array}{c}\text { Recovered } \\
(n: 147)\end{array}$ & $\begin{array}{l}\text { Death } \\
(n: 41)\end{array}$ & $\mathbf{P}$ \\
\hline Age(years) & Media (DS) & 59.79 (17.48) & $55.32(15.64)$ & $75.80(14.15)$ & $<0.000$ * \\
\hline \multirow[t]{2}{*}{ Sex } & Femenino & $81(43.09 \%)$ & $64(79.01 \%)$ & $17(20.99 \%)$ & 0.813 \\
\hline & Masculino & 107 (56.91\%) & 83 (77.57 \%) & 24 (22.43 \%) & \\
\hline \multirow[t]{2}{*}{ Hypertension } & No & $145(77.13 \%)$ & $119(82.07 \%)$ & 26 (17.93 \%) & 0.018 \\
\hline & $\mathrm{Si}$ & 43 (22.87\%) & $28(65.12 \%)$ & 15 (34.88 \%) & \\
\hline \multirow[t]{2}{*}{ Diabetes mellitus } & No & $158(84.04 \%)$ & $124(78.48 \%)$ & $34(21.52 \%)$ & 0.825 \\
\hline & $\mathrm{Si}$ & 30 (15.96 \%) & $23(76.67 \%)$ & 7 (23.33) & \\
\hline \multirow{2}{*}{ ESRD } & No & 179 (95.21 \%) & $143(79.89 \%)$ & 36 (20.11 \%) & 0.012 \\
\hline & $\mathrm{Si}$ & 9 (4.79 \%) & 4 (44.44%) & $5(55.56 \%)$ & \\
\hline \multirow[t]{2}{*}{ Asthma } & No & $183(97.34 \%)$ & 145 (79.23 \%) & 38 (20.77 \%) & 0.036 \\
\hline & $\mathrm{Si}$ & 5 (2.66 \%) & $2(40 \%)$ & $3(60 \%)$ & \\
\hline \multirow[t]{2}{*}{ Obesity } & No & $181(96.28 \%)$ & $142(78.45 \%)$ & 39 (21.55 \%) & 0.659 \\
\hline & $\mathrm{Si}$ & 7 (3.72 \%) & 5 (71.43\%) & $2(28.57 \%)$ & \\
\hline \multirow[t]{2}{*}{ Other comorbidities } & No & $133(71.12 \%)$ & 114 (85.71 \%) & $19(14.29 \%)$ & $<0.000$ \\
\hline & $\mathrm{Si}$ & 54 (28.88 \%) & 32 (59.26 \%) & $22(40.74 \%)$ & \\
\hline Leukocytes & Media (DS) & $9.68(4.44)$ & $9.49(4.52)$ & $10.35(4.13)$ & $0.281^{*}$ \\
\hline Lymphocytes & Media (DS) & $1.44(0.88)$ & $1.59(0.90)$ & $0.90(0.53)$ & $<0.000^{*}$ \\
\hline CRP & Media (DS) & 94.04 (95.61) & 82.34 (88.95) & $136.48(107.50)$ & $0.001^{*}$ \\
\hline pO2 & Media (DS) & $83.73(24.39)$ & $83.94(22.28)$ & $82.98(31.18)$ & $0.827^{\star}$ \\
\hline pCO2 & Media (DS) & $33.40(5.06)$ & $33.32(4.96)$ & 33.67 (5.47) & $0.699^{*}$ \\
\hline Sat $\mathrm{O2}$ & Media (DS) & $95.73(8.74)$ & $95.23(5.10)$ & 97.55 (16.09) & $0.138^{*}$ \\
\hline Admission days & Media (DS) & $11.75(9.04)$ & $10.88(7.08)$ & $14.82(13.59)$ & $0.013^{*}$ \\
\hline TSS Score & Media (DS) & 7.33 (3.50) & 6.59 (3.03) & $10.05(3.80)$ & $<0.000^{* *}$ \\
\hline RDW & Media (DS) & $13.323(1.284)$ & $12.971(1.081)$ & 13.411(1.715) & $<0.003^{\star \star}$ \\
\hline
\end{tabular}

Table 2. Multivariate Analysis Using Binary Logistic Regression to Predict Mortality

\begin{tabular}{lccc}
\hline & Adjusted OR & $\mathbf{p}$ & $\mathrm{Cl} \mathrm{95 \%}$ \\
\hline RDW & 1.67 & 0.004 & $1.18-2.35$ \\
Lymphocytes & 0.27 & 0.012 & $0.09-0.74$ \\
Age & 1.08 & $<0.001$ & $1.04-1.13$ \\
\hline
\end{tabular}

Disclosure of Interests: Jorge Ravelo Speakers bureau: Less than 10 speech for Grunenthal and Novartis, Paid instructor for: 1 time for Riverpharma, Grant/ research support from: I am working as PI doing sponsored clinical trials since 2008

DOI: 10.1136/annrheumdis-2021-eular.4212

\section{AB0711}

\section{FOLLOW-UP OF PATIENTS UNDER BIOLOGICS IN THE} ERA OF LOCKDOWN

V. F. Boussougou ${ }^{1}$, K. Nassar ${ }^{1}$, S. Janani ${ }^{1} .{ }^{1}$ University Hospital of Ibn Rochd, Department of Rheumatology, Casablanca, Morocco

Background: The management of patients with inflammatory rheumatic diseases under biologics has raised many questions about the global management of patients in the time of COVID-19 pandemic. This period could have been particularly painful for the patients due to the virus itself, and to the difficulty to access to healthcare facilities due to the lockdown.

Objectives: To assess the impact of the lockdown in patients under biologics.

Methods: This is a descriptive study, conducted between 03/01/2021 and 07/31/2021 in the Department of Rheumatology of the University Hospital o Ibn Rochd in Casablanca. Inclusion criteria were all patients on biologics during the lockdown period. The number of painful, swollen joints, pain visual analogue scale, and disease activity were collected before and during the lockdown.

Results: Thirty-one patients under biologics were included. The average age was 43.4 years. There were 17 males and 14 females (sex ratio $M / F ~ 1,21$ ). Cormibidities were hypertension and type 2 diabetes $(9.7 \%)$, hypertension and dyslipidemia (6.5\%), arrhythmia (6.5\%), smoking (9.7\%), hypertension and dysthyroidism (3.2\%). All the patients were under biologics with an average duration of 2 years distributed as follows: 3 patients on etanercept (9.67\%), 8 patients on tocilizumab $(28.8 \%), 10$ patients on infliximab $(32.25 \%), 5$ patients on adalimumab (16.12\%)), 4 patients under golimumab $(12.90 \%), 1$ under secukinumab $(3.22 \%)$. Biologics were associated with conventional synthetic disease-modifying antirheumatic drugs in $38.7 \%$ (methotrexate $12.9 \%$, salosopyrine $25,8 \%$ ), corticosteroids in $25.7 \%$, non-steroidal anti-inflammatory drugs in $16.1 \%$. The disease activity before COVID-19 of the patients was: $48.39 \%$ weak activity, $35.4 \%$ remission, $16.13 \%$ moderate activity. No patient reported a flare of the disease. During lockdown, 5 patients reported a flare of their disease $(16.12 \%)$ They were followed for: 2 spondyloarthritis, 1 rheumatoid arthritis, 1 psoriatic arthritis, 1 adult onset Still's disease. All the patients have temporarily stopped their drugs because they couldn't come to their appointments because of the lockdown.

Conclusion: Our study notes that the patients who kept their follow-up during lockdown have maintained a control of their disease activity. Our results are consistent with the observations of a French study on the impact of lockdown on the activity of rheumatoid arthritis. However, those who couldn't come to their control appointment due to the lockdown had a flare of their disease. This study remains limited due to the monocentric nature and the small size of our sample.

Disclosure of Interests: None declared

DOI: 10.1136/annrheumdis-2021-eular.4271

\section{AB0712 THE INCIDENCE OF SARS-COV-2 INFECTION IN PATIENTS WITH RHEUMATIC DISEASES ON THERAPY BIOLOGICAL DISEASE MODIFYING ANTIRHEUMATIC DRUGS}

A. Dadalova ${ }^{1}$, E. Vasilenko ${ }^{1}$, R. Samigullina ${ }^{1}$, V. Mazurov ${ }^{1} .{ }^{1}$ North-Western State Medical University named after I.I. Mechnikov, Department of Therapy, 
Rheumatology, Examination of Temporary Disability and Quality of Medical Care named after E.E.Eichwald, St. Petersburg, Russian Federation

Background: At the moment, a highly relevant issue is the course of SARSCoV-2 infection in patients with rheumatic pathology, especially, those receiving therapy with biological disease modifying antirheumatic drugs.

Objectives: of the current study to assess the prevalence and course of SARS CoV-2 infection in patients receiving various biological disease modifying antirheumatic drugs.

Methods: to assess the severity of the course of SARS-CoV-2, discharged epicrisis from hospitals or the conclusion of computed tomography were used. The average age of the patients ranged from $41.4+11.6$ years. In the evaluated sample, 47 patients $(49.47 \%)$ were males. Among the infected of SARS-CoV-2 were patients with rheumatoid arthritis - $45(47.4 \%)$, spondyloarthritis - 39 (41.1\%) systemic connective tissue diseases - $11(11.5 \%)$

Results: Since March 2020, among the 1319 patients with rheumatic diseases observed at the St. Petersburg Center of therapy biological disease modifying antirheumatic drugs, 95 patients $(7,2 \%)$ had SARS-CoV-2 infection. In $57,9 \%$ ( 55 patients) there was a mild course of infection, in $35,8 \%$ of cases (34 patients) - a moderate course, in $6,3 \%$ (6 patients) - a severe course. Inpatient treatment was received by $29,5 \%$ ( 28 patients). A favorable outcome was noted in $95.8 \%$, and a lethal outcome in $4,2 \%$. The use of interleukin- 6 inhibitors was required in $2,1 \%$ of patients (2) due to the development of a cytokine storm. The structure of the received biological therapy in the severity of the course is shown in Table 1

Table 1. The structure of the received biological therapy in the severity of the course SARS-CoV-2 infection

\begin{tabular}{|c|c|c|c|c|c|}
\hline & Mild course & $\begin{array}{l}\text { CT-1 } \\
(<25 \%)\end{array}$ & $\begin{array}{l}\text { CT-2 } \\
(25-50 \%)\end{array}$ & $\begin{array}{l}\text { CT-3 } \\
(50-75 \%)\end{array}$ & $\begin{array}{l}\text { CT-4 } \\
(>75 \%)\end{array}$ \\
\hline TNF- $\alpha$ inhibitors, $n(\%)$ & $30(31,6)$ & $11(11,6)$ & $7(7,3)$ & $3(3,2)$ & $0(0,0)$ \\
\hline $\begin{array}{l}\text { anti B-cell therapy (rituximab), } \\
\text { n (\%) }\end{array}$ & $2(2,1)$ & $1(1,1)$ & $2(2,1)$ & $1(1,1)$ & $2(2,1)$ \\
\hline Abatacept, n (\%) & $3(3.2)$ & $0(0,0)$ & $2(2,1)$ & $0(0,0)$ & $0(0,0)$ \\
\hline Janus kinase inhibitors, $\mathrm{n}(\%)$ & $5(5,3)$ & $1(1,1)$ & $1(1,1)$ & $0(0,0)$ & $0(0,0)$ \\
\hline Interleukin-6 inhibitors, n (\%) & $6(6,3)$ & $0(0,0)$ & $0(0,0)$ & $0(0,0)$ & $0(0,0)$ \\
\hline Interleukin-17 inhibitors, n (\%) & $8(8,4)$ & $2(2,1)$ & $2(2,1)$ & $0(0,0)$ & $0(0,0)$ \\
\hline Other, $\mathrm{n}(\%)$ & $1(1,1)$ & $4(4,2)$ & $1(1,1)$ & $0(0,0)$ & $0(0,0)$ \\
\hline
\end{tabular}

Among 95 infected patients, who were observed in the center, 51 received therapy with TNF- $\alpha$ inhibitors ( $8.5 \%$ of the total number of patients receiving therapy), 8 - rituximab therapy (2.7\%), 5 - abatacept $(6.3 \%), 7$ - Janus kinase inhibitors $(0.9 \%), 6$ - interleukin- 6 inhibitors (9.2), 12 - interleukin -17 inhibitors (14.1\%), 6 patients treated with other drugs $(10 \%)$.

Conclusion: Taking into account the SARS-CoV-2 pandemic, further study of the course of infection in patients with rheumatic diseases including those receiving biological therapy, is required. More information is also needed on the safety and efficacy of vaccination in this patient population.

Disclosure of Interests: None declared

DOI: 10.1136/annrheumdis-2021-eular.4323

\section{Pain in rheumatic diseases, including fibromyalgia}

\begin{tabular}{|l}
\hline AB0713 \\
EVALUATION OF THE EFFECTIVENESS OF LASER \\
THERAPY IN THE TREATMENT OF RHEUMATOID \\
ARTHRITIS
\end{tabular}

N. Zhuravleva ${ }^{1}$, L. Karzakova2, S. Kudryashov3, E. Petrova ${ }^{4} .{ }^{1}$ Federal State Budgetary Educational Institution of Higher Education "The Chuvash State University named after I.N. Ulyanov", Department of Internal Medicine, Cheboksary, Russian Federation: ${ }^{1}$ Federal State Budgetary Educational Institution of Higher Education "The Chuvash State University named after I.N. Ulyanov", Department of Internal Medicine, Cheboksary, Russian Federation; ${ }^{1}$ Federal State Budgetary Educational Institution of Higher Education "The Chuvash State University named after I.N. Ulyanov", Department of Internal Medicine, Cheboksary, Russian Federation; ${ }^{4}$ Federal State Budgetary Educational Institution of Higher Education" The Chuvash State University named after I.N. Ulyanov", Department of Instrumental Diagnostics, Cheboksary, Russian Federation
Background: Despite the fact that the introduction of biological disease-modifying antirheumatic medicines (bDMARDs) and the early start of treatment for rheumatoid arthritis (RA) can effectively stop the inflammatory process in RA, a fairly large number of patients continue to experience joint pain [1]. It is assumed that in some cases, joint pain in patients with RA is not associated with the inflammation, so it requires consideration of the possibility of using alternative strategies for the treatment of RA.

Objectives: The aim of the research is to study the effectiveness of laser therapy in the treatment of RA.

Methods: 114 patients with RA aged from 32 to 53 years have been monitored for 6 months. There were 82 women $(71.9 \%)$ and 32 men $(28.1 \%)$ among them. The patients were randomly divided into 2 groups. The first group of patients (57 people) received basic medical therapy with methotrexate $15 \mathrm{mg}$ intramuscularly once a week and nonsteroidal anti-inflammatory medicines (NSAIDs) on demand. The dose of methotrexate was selected taking into account the disease activity index DAS 28. The second group of patients ( 57 people) received basic medical therapy with methotrexate $15 \mathrm{mg}$ intramuscularly once a week and NSAIDs on demand. In addition, the cutaneous low-intensity laser irradiation of the joints was added along the projection of the joint gap in a pulse mode with a wavelength of 0.89 microns. The pulse frequency is $80-1500 \mathrm{~Hz}$, the pulse power is $5 \mathrm{~W}$, the exposure time in the field is $1-2$ minutes and the total radiation time per session is no more than 10 minutes [2]. The course of treatment consisted of 10 procedures (the device "Milta F-8 RD", Russia, Moscow). The course of laser therapy was repeated after 4 weeks. To assess clinical indicators, patients were examined using the SF-36 questionnaire before treatment and 6 months after the start of treatment.

Results: The survey after 6 months revealed the significant decrease in the severity of pain on the VAS from the initial average indicator $4.5 \pm 0.2$ to $3.69 \pm 0.2$ points $(p<0.01)$ and morning stiffness from $60 \pm 5$ to $40.8 \pm 4$ minutes $(p<0.01)$. In the first group, the dynamics of clinical indicators were not statistically significant: the intensity of pain decreased from $4.6 \pm 0.2$ to $4.2 \pm 0.3$ points ( $p>0.05$ ) and the duration of morning stiffness reduced from $62 \pm 7$ to $58.6 \pm 6$ minutes $(p>0.05$ ). In the second group the decrease in the need for NSAIDs was observed in 21 patients, while in the first group the same was observed only in 10 patients $\left(p_{x 2}\right.$ $=0.020$ ).

Conclusion: Laser therapy in the treatment of patients with RA enabled to decrease the frequency of the need for NSAIDs and reduce morning stiffness We recommend using laser therapy in patients with RA at the second radiological stage as an addition to basic therapy. REFERENCES:

[1] Altawil R et al. Arthritis Care Res (Hoboken). 2016; 68(8): 1061-1068.

[2] Burger M et al. Physiother Theory Pract. 2017; 33(3): 184-197.

Disclosure of Interests: None declared

DOI: 10.1136/annrheumdis-2021-eular.238

\section{$\mathrm{AB} 0714$ \\ COMPARISON OF THE EFFECT OF SUBACROMIAL ADMINISTRATION OF HYALURONIC ACID AND PLATELET RICH PLASMA IN CASES OF DAMAGE TO THE TENDONS OF THE ROTATORS OF THE SHOULDER IN INDIVIDUALS OF DIFFERENT AGE GROUPS}

V. Nesterenko ${ }^{1,1}$, A. Karateev ${ }^{1}$, E. Bialik ${ }^{1}$, M. Makarov ${ }^{1}$, S. Makarov ${ }^{1}$ V. Bialik', M. Nurmukhametov ${ }^{1}$, A. Chernikova ${ }^{1} .{ }^{1}$ V.A. Nasonova Research Institute of Rheumatology, Rheumatology, Moscow, Russian Federation

Background: Everyone has had shoulder pain at least once in their life. From 70 to $80 \%$ of chronic pain in the shoulder joint is associated with subacromial impingement syndrome. The use of non-steroidal anti-inflammatory drugs (NSAIDs) and glucocorticoids does not always meet the needs of patients and have a number of adverse reactions. Local administration of PRP and HA preparations is widely used for chronic shoulder pain. However, the question of the effectiveness of these drugs in patients of different ages has been insufficiently studied.

Objectives: To compare the efficacy of GLA and PRP in patients with chronic shoulder pain by age.

Methods: The study group included 100 patients, $46 \%$ women and $54 \%$ men, aged $51.5 \pm 15.1$, with chronic shoulder pain ( $\geq 3$ months) caused by damage to the tendons of the muscles of the shoulder rotators. Patients $<45$ years old accounted for $34 \%$, patients $\geq 45$ years old - $66 \%$. All patients were randomly divided into 2 groups. Patients in group 1 received 2 consecutive subacromial injections of GLK, groups 2 - 3 consecutive subacromial injections of PRP. Pain dynamics were assessed using a 100-mm visual analogue scale (VAS) 